\title{
Muhasebe Meslek Mensuplarının Dijital Muhasebe Uygulamalarını Kullanımlarına ilişkin Bir Araştırma ${ }^{1}$
}

\author{
Yasin ŞEKER ${ }^{2}$ - Safa HOŞ ${ }^{3}$
}

Başvuru Tarihi: 18.07.2021 Kabul Tarihi: 31.10.2021 Makale Türü: Araştırma Makalesi

\section{Öz}

Teknolojik gelişmelere paralel olarak gelişen dijitalleşme ile birlikte pek çok alan ve meslekte olduğu gibi muhasebe alanında da köklü dönüşümler olmuştur. Bu çalışmanın amacı Çorum ilinde bağımsız olarak görev yapan Serbest Muhasebeci Mali Müşavirlerin (SMMM) dijital muhasebe uygulamalar kullanımına ilişkin görüşlerini belirlemek ve kullanıma etki eden faktörlerin neler olduğunu tespit etmektir. Anket yönteminin kullanıldığı bu çalışmada geçerli ve güvenilir olduğu yapılan çalışmalarla ispatlanmış olan Teknoloji Kabul Modeli (TKM) ölçeğinden yararlanılmıştır. Dijital muhasebe uygulamalarına uyarlanarak kullanılan ölçek toplam 14 ifadeden oluşmaktadır. Demografik özellikleri belirleyebilmek için ise 4 soru bulunmaktadır. Analiz kapsamında SMMM'lerin dijital muhasebe uygulamaları ile ilişkili olarak; algılanan kullanım kolayliğının algılanan fayda, algılanan kullanım kolaylı̆ının kullanma niyeti ve algılanan faydanın kullanma niyeti üzerindeki etkisi yapısal eşitlik modeli kullanılarak incelenmiştir. Elde edilen sonuçlara göre dijital muhasebe uygulamalarına yönelik SMMM'lerin algıladıkları faydanın, kullanma niyeti üzerinde pozitif bir etkisinin olduğu tespit edilmiştir. Ancak dijital muhasebe uygulamalarına yönelik SMMM’lerin algıladıkları kullanım kolaylı̆̆ının, algıladıkları fayda ve kullanma niyeti üzerinde pozitif yönlü bir etkisi olmakla birlikte bunun istatistiksel olarak anlamlı olmadı̆̆ belirlenmiştir.

Anahtar Kelimeler: Muhasebe Meslek Mensubu, Dijital Muhasebe Uygulamaları, Algilanan Fayda, Algılanan Kullanım Kolaylı̆̆, Kullanma Niyeti

Atıf: Şeker, Y. ve Hoş, S. (2021). Muhasebe meslek mensuplarının dijital muhasebe uygulamalarını kullanımlarına ilişkin bir araştırma. Anadolu Üniversitesi Sosyal Bilimler Dergisi, 21(4), 953-972.

\footnotetext{
${ }^{1}$ Bu çalışma için etik kurul izin belgesi Hitit Üniversitesi Girişimsel Olmayan Araştırmalar Etik Kurulu'ndan 05.04.2021 tarih ve 2021/63 sayllı olarak alınmıştır.

${ }^{2}$ Hitit Üniversitesi İktisadi ve İdari Bilimler Fakültesi İșletme Bölümü, yasinseker01@gmail.com, ORCID: 0000-0003-0513-7682

${ }^{3}$ Hitit Üniversitesi İktisadi ve İdari Bilimler Fakültesi İșletme Bölümü, safahos@hitit.edu.tr, ORCID: 0000-0002-9555-1782
} 


\title{
Digital Accounting Practices: A Study of Professional Accountants
}

\author{
Yasin ŞEKER ${ }^{4}$ - Safa HOŞ ${ }^{5}$
}

Submitted by: 18.07 .2021

Accepted by: 31.10 .2021

Article Type: Research Article

\begin{abstract}
Digitalization, which has developed in parallel with technological developments, has resulted in radical transformations in the field of accounting, as well as in many other fields and professions. The purpose of this study is to determine CPAs' perspectives on their use of digital accounting practices, as well as to ascertain what factors influence digital accounting practices. This survey-based study employed the Technology Acceptance Model (TAM) scale. The scale, which is used by adapting to digital accounting practices, consists of 14 statements in total. There are also 4 questions to determine demographic characteristics. The collected data have been analyzed using structural equation modeling to test the impact of ease of use on perceived usefulness, ease of use on behavioral intention, and perceived usefulness on behavioral in relation to CPA's digital accounting practices. According to the findings, CPAs' perceived usefulness for digital accounting practices has a positive effect on their intention to use it. It has been determined, however, that CPAs' perceived ease of use for digital accounting practices has a positive effect on their perceived usefulness and behavioral intention, but this is not statistically significant.
\end{abstract}

Keywords: Professional Accountant, Digital Accounting Practices, Perceived Usefulness, Perceived Ease of Use, Behavioral Intention

\footnotetext{
${ }^{4}$ Hitit University, Faculty of Economics and Administrative Sciences, Department of Business Administration, yasinseker01@gmail.com, ORCID: 0000-0003-0513-7682

5 Hitit University, Faculty of Economics and Administrative Sciences, Department of Business Administration, safahos@hitit.edu.tr, ORCID: 00000002-9555-1782
} 


\section{Giriş}

Bilgi teknolojilerindeki gelişmelerle birlikte verilerin ve bilgilerin işlenmesi, elde edilmesi ve raporlanması daha kolay ve hızlı bir hale gelmiştir. Bu durum tüm dünyada dijital dönüşümü kaçınılmaz kılmıştır (Gökçen ve Özdemir, 2016, s. 138; Erdoğan, 2020, s. 6). Kurum ve kuruluşlar faaliyetlerini etkin ve verimli bir şekilde sürdürebilmek için mevcut sistemlerinde dijital dönüşümü gerçekleştirmeye başlamıştır. Muhasebe bu değişimden oldukça etkilenen alanlardan birisidir. Dijital dönüşümle birlikte muhasebede geleneksel kayıt tutma yöntemlerinin sınırlılıkları ortadan kalkmış, bilginin saklanması, bilgiye ulaşım, verilerin kontrol edilmesi ve karşılaştırmalarda kullanılması kolaylaşmıştır. Böylelikle dijital muhasebe anlayışı yenilikçi bir dönüşümle ortaya çıkmıştır (Arslan ve Karkacıer, 2019, s. 430).

Muhasebenin ürettiği bilgilerin bilgi kullanıcılarına gerçeğe uygun olarak zamanında sunulması ve güvenilir bir şekilde saklanması gereklidir (Erturan ve Ergin, 2018, s. 217; Esmeray, 2018, s. 306). Dijital dönüşüm bu bilgilerin zamanında sunulmasını ve güvenilir bir şekilde saklanmasını sağlamakla birlikte denetim faaliyetlerinin daha hızlı ve şeffaf bir şekilde yürütülmesine de katkı sağlamaktadır (Arslan ve Demirkan, 2019, s. 54). Zira bilgi teknolojilerindeki gelişmelerle birlikte ortaya çıkan sistemler, verinin kolay bir şekilde toplanması, saklanması ve analizlerinin yapılması sağlamakla birlikte büyük hacimli veriye hızlı bir şekilde erişimi de mümkün hale gelmiştir (Akdoğan ve Akdoğan, 2018, s. 1). Bu gibi avantajları nedeniyle muhasebe alanında dijital dönüşüm hızlı bir şekilde yer bulmuştur. 2000 yılında muhasebedeki tüm bilgilerin sadece \%25'ine denk gelen kısmı dijitalken, 2017 yılına gelindiğinde bu oranın \%98'e ulaşması muhasebedeki dijital dönüşümün en net göstergelerinden birisidir (Aslan ve Özerhan, 2017, s. 868).

Muhasebe uygulamalarında dijital dönüşüm; kayıt, belgeleme, arşiv, raporlama ve personel üzerinde köklü değişimlere neden olmuştur. Geleneksel deftere kayıtlar yerini elektronik ortamda kayıtlara bırakmıştır. Belgeler elektronik ortamda düzenlenmeye ve alıcıya ulaştıılmaya başlanmıştır. Yapılan işlemler, dijital imza da kullanılarak, güvenli bir şekilde izlenilebilir hale gelmiştir. Arşivler fiziki ortamdan dijital ortama taşınmış ve güvenli bir ortamda verilerin korunması ihtiyacı ortaya çıkmıştır. Raporların geleneksel yöntemlere göre elektronik ortamda kolaylıkla hazırlanabilmesiyle raporlama süreci hızlı bir şekilde gerçekleşmeye başlamıştır. Personel noktasında ise mesleki bilginin yanı sıra dijital araçların kullanımına da hâkim olması zorunlu bir hal almıştır (Güney ve Özyiğit, 2015, s. 290; Erdem ve Gülten, 2021, s. 7). Tüm bu gelişmeler ile birlikte muhasebede çeşitli yazılım programları ve elektronik uygulamalar kullanılmaya başlanmıştır. Aynı zamanda devlet muhasebesindeki dijital dönüşüme entegre bir şekilde 2005 yllında e-Beyanname, 2010 yılında E-Fatura, 2013 yılında e-Defter ve e-Arşiv Fatura, 2018 yılında e-İrsaliye, e-Müstahsil Makbuzu ve e-Serbest Meslek Makbuzu uygulamaları kullanılmaya başlanmıştır (Şençiçek Tektüfekçi, 2013; Tektüfekçi, 2019).

Dijital muhasebe uygulamalarının meslek mensuplarına doğruluk, zamanında sunum, verilerin saklanması ve güvenilirlik gibi faktörlerde önemli katkılar sağladığı söylenebilir. Bu nedenle muhasebe meslek mensuplarının dijital muhasebe uygulamaları için algılanan kullanım kolaylığı ve algılanan fayda düzeyi gibi faktörlerin incelenmesi bu uygulamaların daha etkin ve verimli kullanılmasında önem arz etmektedir. Bu doğrultuda çalışmada SMMM'lerin dijital muhasebe uygulamalarına yönelik olarak algıladıkları fayda, algıladıkları kullanım kolaylığı ve uygulamaları kullanma niyetlerini belirlemeye yönelik bir araştırma yapılmıştır.

Çalışmanın izleyen bölümleri şu şekilde devam etmektedir. İzleyen bölümde literatür taraması yer almaktadır. Daha sonraki bölümde araştırmanın amacı, önemi, veri seti ve özellikleri tanımlanmaktadır. Bu bölümü takiben ise yapılan analizler sonucunda elde edilen bulgular yer almaktadır. Son olarak sonuç ve tartışmalara yer verilerek çalışma tamamlanmaktadır. 


\section{Literatür Taraması}

Dijital muhasebe uygulamalarına yönelik olarak yapılan literatür taraması sonucunda ulaşılan çalışmalara dair bilgiler aşağıda yer almaktadır.

Dinç ve Karakaya (2004) Doğu Karadeniz bölgesindeki muhasebe meslek mensuplarının genel özelliklerinin elektronik muhasebe uygulamaları üzerine etkisini belirlemeyi amaçlamıştır. Anket tekniğiyle toplanan verilerden elde edilen analiz sonuçlara göre, elektronik muhasebe uygulamalarını muhasebe meslek mensuplarından yaşı daha küçük olanların daha fazla kullandığı, cinsiyet açısından bir farklılık bulunamadı̆̆ı, eğitim seviyesinin artmasıyla bilgi teknolojilerinin kullanım oranının arttığı ve yüksek gelir düzeyine sahip olanlar ile daha tecrübelilerin elektronik muhasebe uygulamalarını daha fazla kullandığı tespit edilmiştir.

Özer ve diğerleri (2010) muhasebe meslek mensuplarının bilgi teknolojilerin kullanımlarını TKM ile incelemiştir. Analizler sonucunda algılanan fayda ve kullanım kolaylığının bilgi teknolojilerini kullanım davranışına yönelik niyet üzerinde pozitif bir etkisinin olduğu ve bu niyetin de gerçekleşen davranış üzerinde pozitif bir etkiye sahip olduğu tespit edilmiştir.

Hatunoğlu ve Bakan (2010) muhasebe meslek mensuplarının muhasebe bürolarında bilgisayar ve internet kullanımının sağladığı faydalara ilişkin görüşlerini belirlemeye yönelik Gaziantep ve Kahramanmaraş illerinde anket araştırması yapmıştır. Yapılan analizler sonucunda internet ve bilgisayar kullanımının, muhasebe bürolarında verimliliği, bilgi paylaşımı, iş tatmini ve benzeri faktörlerde olumlu yönde etkili olduğu belirlenmiştir.

Özer ve Yılmaz (2010) Mantıklı Eylem Teorisi kapsamında muhasebe meslek mensuplarının bilgi teknolojileri kullanımına ilişkin durumlarını incelemiştir. Anket yöntemiyle toplanan verilerin analizi sonucunda niyetinin kullanım davranışı üzerinde pozitif bir etkisinin olduğu ve bilgi teknolojilerini kullanım niyeti ile tutum ve subjektif normlar arasında pozitif bir ilişki olduğu tespit edilmiştir.

Çınar ve Güney (2012) muhasebe meslek mensuplarının elektronik işlemlerde karşılaştıkları sorunları belirlemek amacıyla Erzurum'da bir anket çalışması yapmıştır. Çalışma sonucunda, elektronik muhasebe uygulamalarına erişimden kaynaklı beyannamelerin zamanında verilememesi, meslek mensuplarının uygulamaları kullanmada yetersiz olması ve mevzuat değişikliklerinin bilişim sistemine eşzamanlı olarak uyarlanmaması gibi sorunların olduğu tespit edilmiştir.

Spoz (2014) çalışmasında Avrupa Birliği’ndeki ülkelerde e-faturanın kullanım durumunu incelemiştir. Araştırma sonucunda işletmelerin e-fatura uygulamasını yaygın olarak kullanmadığı tespit edilmiştir. Bunun nedenlerinin başında ise müşterilerin e-fatura istememesi, sistem maliyeti, karmaşık e-fatura süreçleri ve efaturaya ilişkin çekinceler geldiği belirlenmiştir.

Lian (2015) bulut tabanlı e-fatura uygulamasına ilişkin görüşleri genişletilmiş TKM’ye bağlı olarak belirlemek için Tayvan'da bir anket araştırması yapmıştır. Analiz sonuçlarına göre yeni bir uygulama olan e-faturaya katılımcıların henüz benimsemediği tespit edilmiştir. Ayrıca sosyal etki, e-devlet sistemine güven ve risk algısının e-fatura uygulamasının benimsenmesinde davranışsal niyet üzerinde etkili faktörler olarak belirlenmiştir.

Marinagi ve diğerleri (2015) Yunan işletmelerinde e-faturanın benimsenme ve kullanılma durumunu incelemektedir. Anket tekniğiyle 42 işletmeden elde edilen bilgilere göre e-fatura kullanım oranı düşük olmakla birlikte benimsenme durumu umut verici bulunmuş ve e-faturanın yaygınlaşması noktasında desteklerin verilmesi gerektiği yönünde sonuçlara ulaşılmıştır. 
Serçemeli ve Kurnaz (2016) Erzurum Küçük ve Orta Ölçekli Mükellefler Grup Başkanlığı’nda görev yapan vergi müfettiş ve yardımcılarının bilgi teknolojileri kullanımına yönelik davranışlarını TKM kapsamında incelemiştir. Analizler sonucunda algılanan kullanım kolaylığının davranışa yönelik tutumu ve algılanan faydanın kullanıma yönelik niyeti pozitif bir şekilde etkilediği tespit edilmiştir.

Bayraktar ve Yıldırım (2017) muhasebe meslek mensuplarının elektronik belge sistemin kullanımlarını ve kabullenme durumlarını Karabük ilinde anket yöntemi kullanarak incelemiştir. Analiz sonuçlarına göre muhasebe meslek mensuplarının performans, çaba, sosyal etki ve güven beklentilerinin davranışsal tutumları ile pozitif ilişkili olduğu belirlenmiştir.

Atasel ve Şeker (2017) Türkiye'de muhasebe meslek sınavlarında ve eğitimlerinde Uluslararası Eğitim Standartları ve Uluslararası Eğitim Uygulama Açıklamaları kapsamında bilgi teknolojilerine verilen önemi belirmeyi amaçlamıştır. İçerik analizi sonucunda staja giriş, SMMM yeterlilik, Özel SMMM ve YMM sınavlarında bilgi teknolojilerini içeren ders ve konuların yer almadığı, TESMER tarafından verilen e-stajyer eğitiminde ise bilgi teknolojileriyle ilgili konuların yer aldığı belirlenmiştir.

Gönen ve Solak (2017) muhasebe meslek mensuplarının elektronik muhasebe uygulamalarına ilişkin görüşlerini tespit etmeye yönelik İzmir'de anket yöntemiyle bir araştırma yapmıştır. Çalışmada meslek mensuplarının elektronik dönüşümden kaynaklı maliyetlerin yüksek olması nedeniyle bunlardan kaçınmaya çalıştıkları, internet kaynaklı sorunların olduğu, teknik alt yapı noktasında kullanılan programların yeterli olduğu ve bu konuda eğitim verilmesinin ihtiyacı olduğu tespit edilmiştir.

Tektüfekçi (2017) çalışmasında Türkiye'deki elektronik muhasebe uygulamalarının gelişim sürecini incelemiş, betimleyici istatistiklere ve örnek olaylara yer vermiştir. Periyodik aralıklarla yapılan araştırma sonuçlarına göre Türkiye'de elektronik muhasebe uygulamalarının kullanımında 2013 ile 2017 yılları arasında oldukça ciddi bir artış yaşandığı tespit edilmiştir. Sonuç olarak akademik ile uygulama taraflarının bilgilerinin birleştirilmesi ve öğrencilere bu öğrenimlerin kazandırılması önerilmiştir.

Elçin ve diğerleri (2018) elektronik muhasebe uygulamalarına geçişte muhasebe meslek mensuplarının yaşadıkları sorunları belirleyebilmek için bir anket araştırması gerçekleştirmiştir. Elde edilen sonuçlara göre her belge bir fiş düzenlenmesi ve her aya ilişkin beratların alınmasının zorunlu olması meslek mensuplarının iş yükünü arttırmaktadır. Sistemsel eksikliklerin olması nedeniyle elektronik muhasebe uygulamalarında iyileştirmelerin yapılmasının gerektiği bir diğer tespittir. Ayrıca alt yapı ve kalifiye eleman noktasında meslek mensuplarının önemli sayılabilecek eksikliklerin olduğunu belirttikleri tespit edilmiştir.

Karasioğlu ve Garip (2019) muhasebe meslek mensuplarının elektronik muhasebe uygulamalarında karşılaştıkları sorunları tespit etmeyi ve çözüm önerileri sunmayı amaçlamışlardır. Çalışmada anket yöntemi kullanılmış olup Karaman SMMM Odasına kayıtlı 138 meslek mensubu üzerinden analizler yapılmıştır. Sonuç olarak elektronik muhasebe uygulamalarının iş yükünü arttırdığını, alanında uzman eleman eksikliğinin olduğu ve mükelleflerin yeterli seviyede bilgilendirilmediği tespit edilmiş olup alt yapı eksikliklerinin giderilmesi ve elektronik muhasebe uygulamaları konusunda sürekli eğitimlerin verilmesi önerilmiştir.

Bozkurt ve Çakmak (2020) bağımsız denetçilerin bilgisayar destekli denetim programları hakkındaki görüşleri ve TKM çerçevesinde algılanan kullanım kolaylığının gerçekleşme durumunu incelemiştir. Yedi ilde uygulanan anket araştırması sonucunda denetçilerin performans beklentilerinin elde edeceği potansiyel fayda üzerinde olumlu bir etkiye sahip olduğu belirlenmiştir. Ayrıca bilgisayar destekli denetim programından algılanan fayda ile programı kullanma niyeti ve davranışları arasında pozitif bir ilişki bulunmuştur. 
Tosunoğlu ve Öztürkci (2020) muhasebe meslek mensuplarının dijital okuryazarlıkları incelemişlerdir. TR90 Bölgesinde meslek mensupları üzerine yapılan anket araştırması sonuçlarına göre dijital okuryazarlığın ele alındığı teknik, bilişsel ve sosyal alt boyutlarının muhasebe mesleği üzerinde pozitif yönlü etkisi olduğu tespit edilmiştir.

Özcan ve Günlük (2021) muhasebe meslek mensuplarının genişletilmiş TKM kapsamında Türkiye Finansal Raporlama Standartları (TFRS) kabullerini etkileyen faktörleri araştırmıştır. Analiz sonuçlarına göre TFRS kullanımı sırasında kolaylaştırıcı faktörlerin algılanması durumunda meslek mensuplarının kullanım kolaylığ 1 algılarının arttığı ve subjektif normların kullanım kolaylığı algısını olumlu yönde etkilediği tespit edilmiştir.

Tuğay ve Güler (2021) tarafından Isparta ilinde muhasebe meslek mensupları üzerinde yapılan çalışmada mülakat tekniğinden faydalanılarak elektronik muhasebe uygulamaları hakkındaki görüşler tespit edilmiştir. Elde edilen sonuçlara göre, meslek mensupları elektronik muhasebe uygulamalarının kullanımının bir gereklilik olduğunu belirtmekle birlikte alt yapı ve bilgi eksikliklerinin olduğunu belirtmektedir.

\section{Araştırma}

$\mathrm{Bu}$ bölümde araştırmanın amacı, önemi, hipotezleri, modeli ve veri setine dair bilgiler yer almaktadır. $\mathrm{Bu}$ araştırma için Hitit Üniversitesi Girişimsel Olmayan Araştırmalar Etik Kurulundan; Tarih: 9.4.2021, Karar No: 2021-63, Sayı: 2021-72 olarak izin alınmıştır.

\section{Araştırmanın Amacı ve Önemi}

$\mathrm{Bu}$ çalışmanın amacı, muhasebe meslek mensuplarının dijital muhasebe uygulamaları kullanımına ilişkin görüşlerini belirlemek ve kullanıma etki eden faktörlerin neler olduğunu tespit etmektir. $\mathrm{Bu}$ amaç doğrultusunda meslek mensuplarının dijital muhasebe uygulamalarına yönelik algılanan fayda, algılanan kullanım kolaylığı ve kullanma niyeti faktörlerine ilişkin görüşleri belirlenerek, bu faktörler arasındaki ilişkiler ortaya konulmuştur. Günümüzde muhasebe uygulamalarının neredeyse tamamının dijital ortamda olduğu düşünüldüğünde muhasebe meslek mensuplarının dijital muhasebe uygulamalarına ilişkin davranışlarının ortaya konulması önem arz etmektedir.

\section{Araştırmanın Hipotezleri ve Modeli}

Bireylerin bilgi teknolojilerine dayalı sistemleri kabullenme ve kullanma niyetlerini belirlemek amaciyla kullanılan TKM, Davis (1989) tarafından geliştirilmiş bir modeldir. Modelin teorik temelleri ise Fishbein ve Ajzen (1975) tarafından geliştirilen Mantıklı Eylem Teorisine (MET) dayanmaktadır. MET ise belirli bir davranış için geçerli olan inançları belirlemeyen genel bir model sunmaktadır. Bu nedenle araştırmacılar öncelikle belirlenen konudaki davranışlarla ilgili inançları tespit etmelidir. Bu kapsamda TKM, bilgi sistemlerinin, kullanıcıların kabulünü modellemek için özel olarak tasarlanmış bir MET uyarlaması olarak ifade edilebilir. TKM'de algılanan fayda ve algılanan kullanım kolaylığı inançları bilgisayar teknolojileri kabul davranışında birinci derecede öneme sahiptir. Algılanan fayda, potansiyel kullanıcının belirli bir uygulama sistemini kullanmasının kurumsal bağlamda iş performansını artıracağına dair subjektif olasılığı olarak tanımlanmaktadır. Algılanan kullanım kolaylığı ise potansiyel kullanıcının hedef sistemin çaba gerektirmemesini beklediği dereceyi ifade etmektedir (Davis, Bagozzi ve Warshaw, 1989, ss. 321-322).

Bu teorik bağlamdan hareketle çalışmanın hipotezleri aşağıdaki gibidir:

$\mathrm{H}_{1}$ : Dijital muhasebe uygulamalarına yönelik SMMM’lerin algıladıkları kullanım kolaylığının, algıladıkları fayda üzerinde pozitif bir etkisi vardır. 
$\mathrm{H}_{2}$ : Dijital muhasebe uygulamalarına yönelik SMMM’lerin algıladıkları faydanın, kullanma niyeti üzerinde pozitif bir etkisi vardır.

$\mathrm{H}_{3}$ : Dijital muhasebe uygulamalarına yönelik SMMM'lerin algıladıkları kullanım kolaylığının, kullanma niyeti üzerinde pozitif bir etkisi vardır.

Çalışma kapsamında belirlenen hipotezleri test etmek için kurulan model toplam 3 değişkenden oluşmaktadır. Algılanan kullanım kolaylığının algılanan fayda, algılanan kullanım kolaylı̆̆ının kullanma niyeti ve algılanan faydanın kullanma niyeti üzerindeki etkisinin incelendiği araştırma modeli Şekil l'de gösterilmiştir.

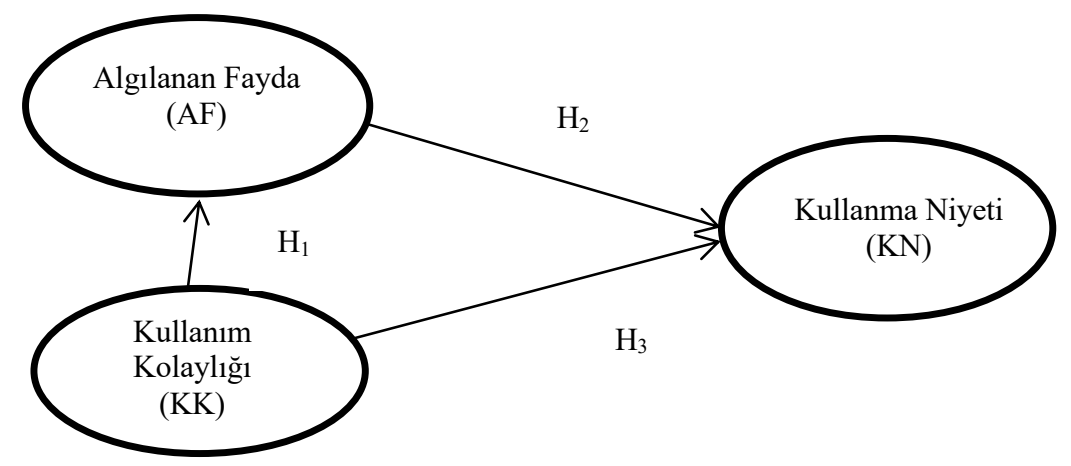

Şekil 1. Araştırma Modeli

\section{Veri Seti ve Özellikleri}

Çalışmanın ana kütlesini Çorum il merkezinde çalışan 209 Serbest Muhasebeci Mali Müşavir oluşturmaktadır. Sayının ulaşılabilir olması nedeniyle tam sayım yöntemi tercih edilmiş ve Google Formlar uygulamasında oluşturulan anket formu ana kütlenin tamamına gönderilmiştir. Geri dönüş sağlayan 95 SMMM'den alınan cevaplar ile çalışma gerçekleştirilmiştir. Anketin ilk bölümünde demografik özelliklere yönelik sorular yer almaktadır. İkinci bölümde ise dijital muhasebe uygulamalarına yönelik ifadeler yer almaktadır. İfadelere yanıtlar için 5’li Likert ölçek kullanılmış ve ölçek '1-Kesinlikle Katılmıyorum, 2-Katılmıyorum, 3-Kararsızım, 4-Katılıyorum, 5-Kesinlikle Katılıyorum’ şeklinde ifade edilmiştir.

Çalışmada SMMM'lerin dijital muhasebe uygulamalarını (elektronik muhasebe uygulamaları) kullanımlarına ilişkin görüşlerini belirlemek amacıyla kullanılan TKM ölçeğinde yer alan ifadeler ve yararlanılan kaynaklar aşağıda tabloda gösterilmiştir. 
Tablo 1

Araştırmada Kullanılan Ölçeğe Dair Bilgiler

\begin{tabular}{|c|c|c|}
\hline Boyutlar & İfadeler & Kaynak \\
\hline \multirow{6}{*}{$\begin{array}{l}\text { Algilanan } \\
\text { Fayda }\end{array}$} & "Dijital muhasebe uygulamalarının kullanımı iş performansımı geliştirir." & \multirow{6}{*}{$\begin{array}{l}\text { Davis (1989); Davis } \\
\text { ve Venkatesh (1996); } \\
\text { Venkatesh ve Bala } \\
\text { (2008)'den aktaran } \\
\text { Erdoğan (2020, s. 65) }\end{array}$} \\
\hline & $\begin{array}{l}\text { "Dijital muhasebe uygulamalarının kullanımı verimliliğimi/üretkenliğimi } \\
\text { artırır." }\end{array}$ & \\
\hline & "Dijital muhasebe uygulamalarının kullanımı işteki etkililiğimi (hedeflerime & \\
\hline & ulaşma derecemi) arttırır." & \\
\hline & $\begin{array}{l}\text { "Dijital muhasebe uygulamalarının kullanımının yararlı olduğunu } \\
\text { düsünüvorum." }\end{array}$ & \\
\hline & $\begin{array}{l}\text { "Dijital muhasebe uygulamalarının kullanımı karmaşı görevleri daha kısa } \\
\text { zamanda gerçekleştirmemi sağlar." }\end{array}$ & \\
\hline \multirow{3}{*}{$\begin{array}{l}\text { Algılanan } \\
\text { Kullanım } \\
\text { Kolaylığı }\end{array}$} & "Dijital muhasebe uygulamalarının kullanımı açık ve anlaşılırdır." & \multirow{3}{*}{$\begin{array}{l}\text { Davis (1989); } \\
\text { Venkatesh ve Bala } \\
\text { (2008)'den aktaran } \\
\text { Erdoğan }(2020 \text {, s. } 65)\end{array}$} \\
\hline & $\begin{array}{l}\text { "Dijital muhasebe uygulamalarını kullanmak çok fazla zihinsel çaba } \\
\text { gerektirmemektedir." } \\
\text { "Dijital muhasebe uygulamalarını kullanmanın kolay olduğunu } \\
\text { düşünüyorum." }\end{array}$ & \\
\hline & $\begin{array}{l}\text { "Dijital muhasebe uygulamalarını kullanarak yapmak istediklerimi kolayca } \\
\text { yaptığımı düşünüyorum." }\end{array}$ & \\
\hline \multirow{5}{*}{$\begin{array}{l}\text { Kullanma } \\
\text { Niyeti }\end{array}$} & "Dijital muhasebe uygulamalarına erişim imkânım olursa bu uygulamaları & \multirow{5}{*}{$\begin{array}{l}\text { Venkatesh ve Bala } \\
\text { (2008)'den aktaran } \\
\text { Erdoğan }(2020 \text {, s. } 65)\end{array}$} \\
\hline & $\begin{array}{l}\text { "Dijital muhasebe uygulamalarına erişimim olduğunda onu kullanabileceğimi } \\
\text { düşünüyorum." }\end{array}$ & \\
\hline & $\begin{array}{l}\text { "Dijital muhasebe uygulamalarını ilerleyen zamanlarda da kullanmayı } \\
\text { planlıyorum." }\end{array}$ & \\
\hline & "Yakın gelecekte, dijital muhasebe uygulamalarını kullanma eğilimindeyim." & \\
\hline & "Görevlerimi yerine getirmek için e-uygulamaları kullanmayı tercih ederim." & \\
\hline
\end{tabular}

Çalışmada kullanılan ölçeğin yapı geçerliliği keşfedici faktör analizi ile ortaya konulmuştur. Örneğin; Davis ve Venkatesh (1996) çalışmalarında TKM ölçeğini değerlendirmek için üç farklı deney uygulamış ve ölçeğin yapı geçerliliğini test etmek için Açıklayıcı Faktör Analizini kullanmıştır. Geçerlilik ve güvenilirlik bakımından incelenen ölçeğin güvenilirliği her deneyde test edilmiş ve deneyler sonucunda Cronbach Alfa'nın 0,90 ve üzerinde değerler aldığı tespit edilmiştir. Böylelikle ölçeğin güvenilir olduğu ortaya konulmuştur $(\alpha>0,70)$. Ölçekte yer alan boyutların içsel tutarlılıklarını gösteren güvenilirlik katsayıları ise algılanan fayda için 0,96, kullanım kolaylığı için 0,94 ve kullanma niyeti için 0,98 olarak bulunmuştur. Bu nedenle bu çalışmada yapı geçerliliği doğrulayıcı faktör analizi ile sınandıktan sonra yapısal eşitlik modeline geçilmiş ve yapısal model için gerekli varsayımlar sağlanmıştır. Çalışmada veri analizi için IBM SPSS ve AMOS paket programlarından faydalanılmıştır.

\section{Bulgular}

$\mathrm{Bu}$ bölümde ilk olarak muhasebe meslek mensuplarının demografik özellikleri ile ilgili soruların değerlendirilmesi yapılmıştır. SMMM'lerin bu sorulara vermiş oldukları cevaplar ise Tablo 2'de gösterilmiştir. 
Tablo 2

Mali Müşavirlerin Demografik Özellikleri

\begin{tabular}{llrr}
\hline Demografik Özellikler & & Frekans & Yüzde(\%) \\
\hline \multirow{2}{*}{ Cinsiyet } & Erkek & 80 & 84,2 \\
& Kadın & 15 & 15,8 \\
\hline \multirow{2}{*}{ Öğrenim Durum } & Lise & 6 & 6,3 \\
& Ön Lisans & 3 & 3,2 \\
& Lisans & 80 & 84,2 \\
& Lisansüstü & 6 & 6,3 \\
\hline \multirow{3}{*}{ Gelir Düzeyi } & $0-3.000 \mathrm{TL}$ & 18 & 18,95 \\
& 3.001 TL-5.000 TL & 17 & 17,9 \\
& 5.001 TL-7.000 TL & 18 & 18,95 \\
& 7.001 TL-9.000 TL & 11 & 11,6 \\
& 9.001 TL-11.000 TL & 6 & 6,3 \\
& 11.000 TL üzeri & 25 & 26,3 \\
\hline \multirow{3}{*}{ 0-5 yll } & 17 & 17,9 \\
& $6-10$ yıl & 8 & 8,4 \\
Mesleki Kıdem & $11-15$ yıl & 14 & 14,7 \\
& $16-20$ yıl & 15 & 15,8 \\
& $21-25$ yll & 17 & 17,9 \\
& 26 yll ve üzeri & 24 & 25,3 \\
\hline
\end{tabular}

Tablo 2'de görüldügü üzere ankete katılan SMMM'lerin \%84'ü erkek ve \%15,8’i kadındır. Öğrenim durumları incelendiğinde \%84'lük bir oranla en yüksek oranın lisans düzeyinde olduğu görülmektedir. Gelir düzeyine ise en yüksek oran \%26 ile 11.000 TL ve üzeri gelir düzeyine sahip olanlardadır. Yaklaşık \%19'luk bir oranda 3.000 TL ve altında gelir belirtildiği görülmekle birlikte muhasebe mesleğine göre bu rakamların, mesleğin ilk yılları için dâhil, oldukça düşük olduğu söylenebilir. Mesleki kıdem incelendiğinde en yüksek oranın \%25 ile 26 yıl ve üzerinde, en düşük oranın ise \%8 ile 6-10 yıl arasında kıdeme sahiplerde olduğu görülmektedir.

Çalışmada modelin ve hipotezlerin test edilmesi amacıyla oluşturulan yapısal eşitlik modeli için "maximum likelihood" yöntemi kullanılmıştır. Bu yöntemin uygulanabilmesi için öncelikle çalışmada kullanılan değişkenlerin normal dağılması gerekmektedir (Hoş ve Bağcı, 2020, s. 120). Modelde yer algılanan fayda, algılanan kullanım kolaylığı ve kullanma niyeti değişkenlerinin normal dağılıp dağılmadığını ve çoklu normallik şartını sağlayıp sağlamadığını test etmek amacıyla değişkenlerin çarpıklık ve basıklık katsayıları bulunmuş ve sonuçlar aşağıdaki Tablo 3’te gösterilmiştir. 
Tablo 3

Normallik Testi Sonuçları

\begin{tabular}{lcccccc}
\hline Değişken & Min. & Maks. & Çarpıklık & CR & Basıllk & CR \\
\hline kn5 & 1 & 5 & $-0,639$ & $-2,542$ & $-1,067$ & $-2,123$ \\
\hline kn4 & 1 & 5 & $-0,769$ & $-3,059$ & $-0,682$ & $-1,357$ \\
\hline kn3 & 1 & 5 & $-0,704$ & $-2,801$ & $-0,876$ & $-1,743$ \\
\hline kn1 & 1 & 5 & $-0,602$ & $-2,394$ & $-0,976$ & $-1,943$ \\
\hline kk1 & 1 & 5 & $-0,685$ & $-2,725$ & $-0,863$ & $-1,716$ \\
\hline kk2 & 1 & 5 & $-0,451$ & $-1,793$ & $-0,670$ & $-1,334$ \\
\hline kk3 & 1 & 5 & $-0,571$ & $-2,273$ & $-0,512$ & $-1,018$ \\
\hline kk4 & 1 & 5 & $-0,453$ & $-1,803$ & $-0,530$ & $-1,054$ \\
\hline af1 & 1 & 5 & $-0,211$ & $-0,840$ & $-0,993$ & $-1,977$ \\
\hline af2 & 1 & 5 & 0,276 & 1,098 & $-1,274$ & $-2,534$ \\
\hline af3 & 1 & 5 & $-0,279$ & $-1,108$ & $-1,076$ & $-2,141$ \\
\hline af4 & 1 & 5 & $-0,340$ & $-1,353$ & $-0,833$ & $-1,658$ \\
\hline af5 & 1 & 5 & $-0,167$ & $-0,663$ & $-0,874$ & $-1,738$ \\
\hline Çok değișkenli & 1 & 5 & $-0,273$ & $-1,085$ & $-0,771$ & $-1,533$ \\
\hline Multivariate) & & & & & 33,469 & 7,706 \\
\hline & & & & & & \\
\hline
\end{tabular}

Çoklu normallik varsayımının sağlanması için ise çok değişkenli kritik oran (multivariate critical ratio) değerinin 10'dan küçük olması beklenmektedir (Kline, 2005). Tablo 2'de yer alan analiz sonucunda değişkenler arasında çoklu normallik varsayımının yerine getirildiği görülmektedir $(7,706<10)$. Ayrıca çarpıklık ve basıklık katsayıları incelendiğinde değişkenlerin çarpıklık ve basıklıklarının-1,5 ile $+1,5$ arasında değerler aldığı görülmekte olup bu sonuçlar modelde kullanılan değişkenlerin normal dağıldığı anlamına gelmektedir (Tabachnick ve Fidell, 2013).

Çalışmada öncelikle ölçüm modelinin değerlendirilmesi için doğrulayıcı faktör analizi kullanılmıştır. Araştırmada yer alan algılanan fayda boyutunu açılamak için 5, algılanan kullanım kolaylığı boyutunu açıklamak için 4 ve kullanma niyeti boyutunu açılamak için 5 madde kullanılmıştır. Çalışmada toplam 3 tane örtük değiş̧ken ve 14 tane gözlenen değişken kullanılarak doğrulayıcı faktör analizi yapılmıştır. Oluşturulan ölçüm modelinin uyumunu değerlendirebilmek için uyum indeksi değerleri hesaplanmış ve sonuçlar Tablo 4’te gösterilmiştir.

Tablo 4

Ölçüm Modeline Ait Uyum İndeksleri

\begin{tabular}{lccc}
$\begin{array}{l}\text { Uyum } \\
\text { Ölçüleri }\end{array}$ & $\begin{array}{c}\text { Mükemmel Uyum İndeksi } \\
\text { Değerleri }\end{array}$ & $\begin{array}{c}\text { Kabul Edilebilir Uyum İndeksi } \\
\text { Değerleri }\end{array}$ & Hesaplanan Uyum İndeksi \\
\hline$\chi^{2} / d f$ & $0 \leq \chi^{2} / d f \leq 2$ & $2 \leq \chi^{2} / d f \leq 3$ & 1,176 \\
\hline GFI & $0,95 \leq G F I \leq 1$ & $0,90 \leq G F I \leq 0,95$ & 0,906 \\
\hline AGFI & $0,90 \leq A G F I \leq 1$ & $0,85 \leq A G F I \leq 0,90$ & 0,839 \\
\hline NFI & $0,95 \leq N F I \leq 1$ & $0,90 \leq N F I \leq 0,95$ & 0,959 \\
\hline IFI & $0,95 \leq I F I \leq 1$ & $0,90 \leq I F I \leq 0,95$ & 0,994 \\
\hline TLI & $0,95 \leq T L I \leq 1$ & $0,90 \leq G F I \leq 0,95$ & 0,990 \\
\hline CFI & $0,95 \leq C F I \leq 1$ & $0,90 \leq C F I \leq 0,95$ & 0,994 \\
\hline RMSEA & $0 \leq R M S E A \leq 0,05$ & $0,05 \leq R M S E A \leq 0,08$ & 0,043 \\
\hline SRMR & $0 \leq S R M R \leq 0,05$ & $0,05 \leq S R M R \leq 0,10$ & 0,050 \\
\hline
\end{tabular}

Kaynak: Schermelleh ve diğerleri (2003), Browne ve Cudeck (1993). 
Tablo 4’te görüldüğü üzere kullanılan ölçeğe yapılan doğrulayıcı faktör analizi sonucunda elde edilen uyum indeksleri uyum kriterlerini sağlamaktadır. Özellikle $\chi^{2} / d f$, GFI, NFI, IFI, TLI, CFI, RMSEA ve SRMR uyum indekslerinin mükemmel uyum değerleri sınırları içerisinde olduğu görülmektedir.

Ölçüm modelinde yer alan boyutları açıklamak için kullanılan değişkenlerin anlamlılığı test edilmiş ve regresyon katsayıları hesaplanmıştır. Doğrulayıcı faktör analizi sonuçlar ise Tablo 5’te gösterilmiştir.

Tablo 5

Ölçüm Modelinin Değerlendirilmesi

\begin{tabular}{|c|c|c|c|c|c|c|c|}
\hline & & & $\begin{array}{r}\text { Standardize } \\
\text { Edilmiş Katsayı }\end{array}$ & $\begin{array}{r}\text { Standardize } \\
\text { Edilmemiş Katsayı }\end{array}$ & S.E. & C.R. & $\mathbf{p}$ \\
\hline af1 & $\leftarrow$ & $\mathrm{AF}$ & 0,697 & 1 & & & \\
\hline af2 & $\leftarrow$ & $\mathrm{AF}$ & 0,748 & 1,002 & 0,15 & 6,657 & $* * *$ \\
\hline af3 & $\leftarrow$ & $\mathrm{AF}$ & 0,72 & 0,997 & 0,142 & 7,036 & $* * *$ \\
\hline af4 & $\leftarrow$ & $\mathrm{AF}$ & 0,916 & 1,233 & 0,139 & 8,881 & $* * *$ \\
\hline af5 & $\leftarrow$ & $\mathrm{AF}$ & 1,014 & 1,269 & 0,142 & 8,918 & $x * *$ \\
\hline $\mathrm{kk1}$ & $\leftarrow$ & $\mathrm{KK}$ & 0,8 & 1 & & & \\
\hline $\mathrm{kk} 2$ & $\leftarrow$ & KK & 0,959 & 1,157 & 0,096 & 12 & $* * *$ \\
\hline kk3 & $\leftarrow$ & KK & 0,956 & 1,149 & 0,095 & 12,09 & $* * *$ \\
\hline $\mathrm{kk} 4$ & $\leftarrow$ & KK & 0,867 & 1,225 & 0,097 & 12,583 & $* * *$ \\
\hline $\mathrm{kn} 1$ & $\leftarrow$ & KN & 0,962 & 1 & & & \\
\hline $\mathrm{kn} 2$ & $\leftarrow$ & $\mathrm{KN}$ & 0,955 & 1,03 & 0,033 & 31,078 & $* * *$ \\
\hline $\mathrm{kn} 3$ & $\leftarrow$ & $\mathrm{KN}$ & 0,99 & 1,038 & 0,041 & 25,106 & $* * *$ \\
\hline $\mathrm{kn} 4$ & $\leftarrow$ & $\mathrm{KN}$ & 0,976 & 1,066 & 0,042 & 25,266 & $* * *$ \\
\hline kn5 & $\leftarrow$ & $\mathrm{KN}$ & 0,804 & 0,999 & 0,082 & 12,206 & $* * *$ \\
\hline
\end{tabular}

Tablo 5’te yer alan analiz sonuçlarına göre boyutları açıklamak için modelde yer alan gözlenen değişkenlerin tümünün ait oldukları boyutları açıklamakta ve ilişkilerin istatistiksel olarak anlamlı olduğu tespit edilmiştir $(\mathrm{p}<0,001)$. Doğrulayıcı faktör analizi sonuçları çalışmada kullanılan ölçeğin yapısını doğrulanmakla birlikte modelin istatistiksel olarak geçerli olduğunu da ortaya koymuştur. Modelde yer alan AF örtük değişkenini açılamak için 5, KK örtük değişkenini açıklamak için 4 ve KN örtük değişkenini açıklamak için 5 gözlenebilir değişken kullanılarak yapısal eşitlik modeli ile değişkenler arasındaki ilişkiler incelenecektir.

Çalışmada kullanılan değişkenler arasındaki ilişkilerin belirlenmesinde Yapısal Eşitlik Modeli kullanılmıştır. Yapısal Eşitlik Modeli ile SMMM’lerin dijital muhasebe uygulamalarına yönelik algılanan faydalarının kullanma niyetleri üzerindeki etkisini, kullanım kolaylığı algılarının kullanma niyetleri üzerindeki etkisini ve kullanım kolaylığı algılarının algılanan fayda üzerindeki etkisini belirlemek amaçlanmıştır.Yapısal eşitlik modeline ait uyum indeksleri ise aşağıda Tablo 6'da gösterilmiştir. 
Tablo 6

Yapısal Eşitlik Modeline Ait Uyum İndeksleri

\begin{tabular}{lccc}
\hline $\begin{array}{l}\text { Uyum } \\
\text { Ölçüleri }\end{array}$ & $\begin{array}{c}\text { Mükemmel Uyum İndeksi } \\
\text { Değerleri }\end{array}$ & $\begin{array}{c}\text { Kabul Edilebilir Uyum İndeksi } \\
\text { Değerleri }\end{array}$ & $\begin{array}{c}\text { Hesaplanan Uyum } \\
\text { İndeksi }\end{array}$ \\
\hline$\chi^{2} / d f$ & $0 \leq \chi^{2} / d f \leq 2$ & $2 \leq \chi^{2} / d f \leq 3$ & 1,095 \\
\hline GFI & $0,95 \leq G F I \leq 1$ & $0,90 \leq G F I \leq 0,95$ & 0,903 \\
\hline AGFI & $0,90 \leq A G F I \leq 1$ & $0,85 \leq A G F I \leq 0,90$ & 0,855 \\
\hline NFI & $0,95 \leq N F I \leq 1$ & $0,90 \leq N F I \leq 0,95$ & 0,959 \\
\hline IFI & $0,95 \leq I F I \leq 1$ & $0,90 \leq I F I \leq 0,95$ & 0,996 \\
\hline TLI & $0,95 \leq T L I \leq 1$ & $0,90 \leq G F I \leq 0,95$ & 0,995 \\
\hline CFI & $0,95 \leq C F I \leq 1$ & $0,90 \leq C F I \leq 0,95$ & 0,996 \\
\hline RMSEA & $0 \leq R M S E A \leq 0,05$ & $0,05 \leq R M S E A \leq 0,08$ & 0,032 \\
\hline SRMR & $0 \leq S R M R \leq 0,05$ & $0,05 \leq S R M R \leq 0,10$ & 0,0384 \\
\hline
\end{tabular}

Kurulan yapısal eşitlik modeli için elde edilen $\chi^{2} / d f$, GFI, NFI, IFI, TLI, CFI, RMSEA ve SRMR uyum indekslerinin mükemmel uyum indeksi değerleri sınırları içerisinde yer aldığı ve uyum kriterlerini sağladığı sonucuna ulaşılmıştır. Modele ait standardize edilmemiş ve standardize edilmiş yol katsayıları Şekil 2 ve 3 'te gösterilmiştir.

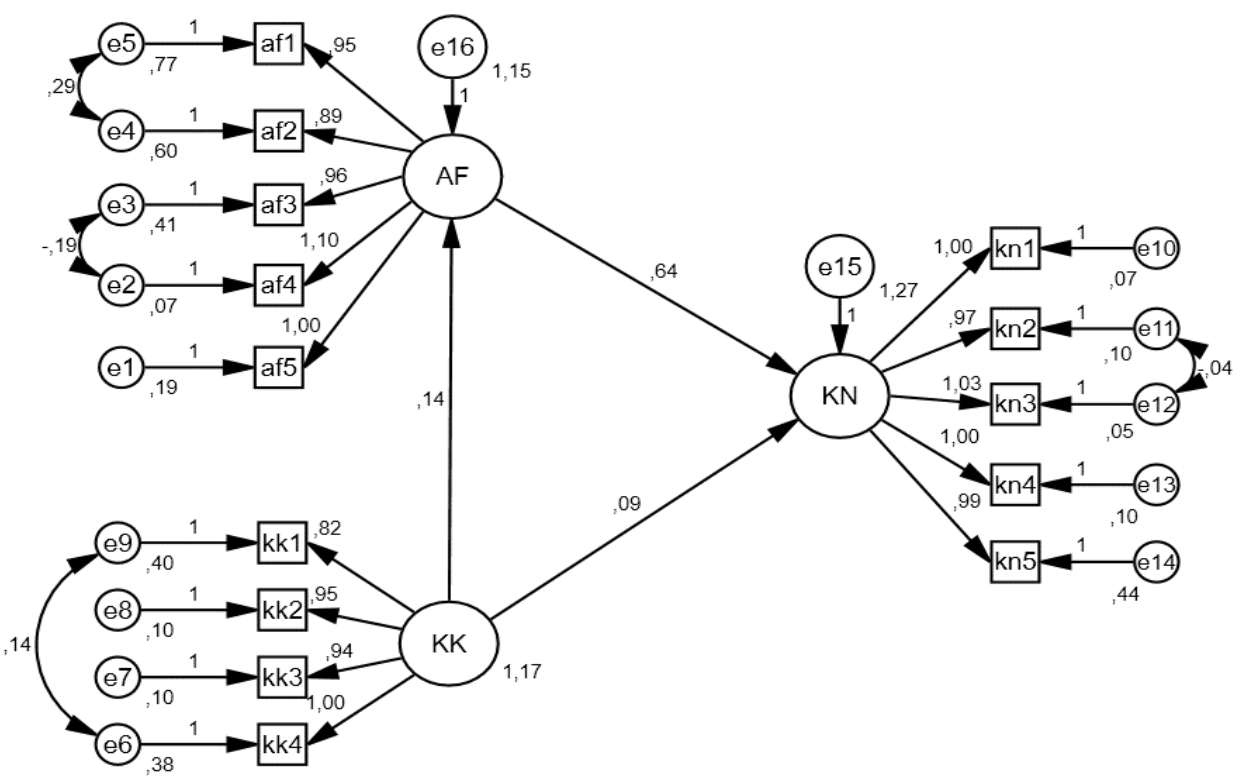

Şekil 2. Standardize Edilmemiş Yol Katsayıları 


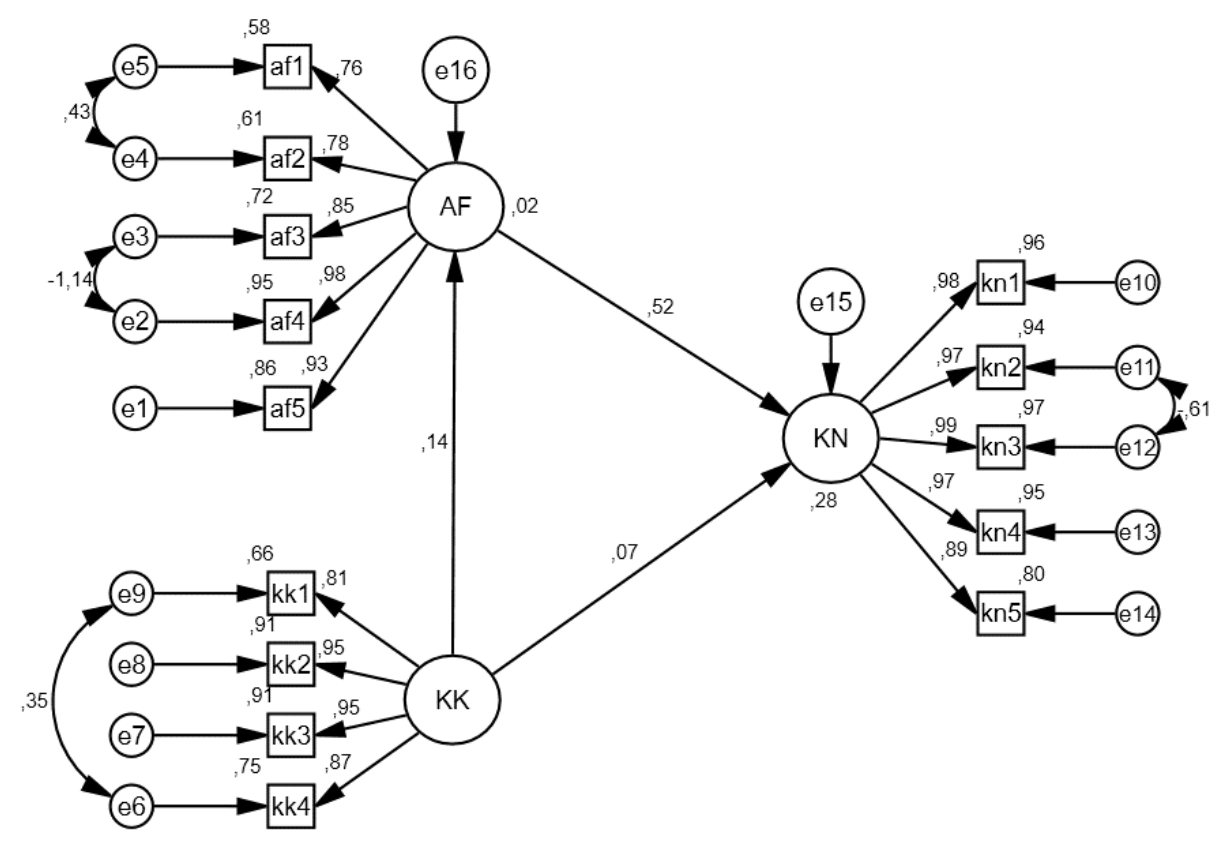

Şekil 3. Standardize Edilmiş Yol Katsayıları

Şekil 3'te yer alan yapısal eşitlik modelinde standardize edilmiş yol katsayıları incelendiğinde SMMM'ler için algılanan fayda değişkeninin kullanma niyeti değişkeni üzerine etkisi 0,52 , algılanan kullanım kolaylı̆̆ değişkeninin kullanma niyeti değişkeni üzerine etkisi 0,07 ve algılanan kullanım kolaylı̆̆ değişkeninin algilanan fayda değişkeni üzerindeki etkisi 0,14 olarak bulunmuştur.

Yapısal eşitlik modelinde veriler ve model arasındaki uyumu arttırmak için çeşitli modifikasyonlar önermektedir. $\mathrm{Bu}$ çalışmada yapısal eşitlik modelinde önerilen modifikasyonlar dikkate alınmış ve bu önerilerden uygun olanlar modele dâhil edilmiştir. Böylece uyum indekslerinde anlamlı artışlar olduğu gözlemlenmiştir. Ayrıca modele dâhil edilen modifikasyonlara ait kovaryans katsayılarının istatistiksel anlamlılıkları test edilmiş ve sonuçlar Tablo 7'de gösterilmiştir.

Tablo 7

Modifikasyonlara Ait İstatistikler

\begin{tabular}{|c|c|c|c|c|c|c|}
\hline & & & Yol Katsayı & S.E. & C.R. & $\mathbf{p}$ \\
\hline $\mathrm{e} 4$ & $\leftrightarrow$ & e5 & 0,289 & 0,08 & 3,636 & $* * *$ \\
\hline e6 & $\leftrightarrow$ & e9 & 0,139 & 0,05 & 2,777 & ** \\
\hline e2 & $\leftrightarrow$ & e3 & $-0,19$ & 0,043 & $-4,389$ & $* * *$ \\
\hline e11 & $\leftrightarrow$ & e12 & $-0,044$ & 0,012 & $-3,532$ & $* * *$ \\
\hline
\end{tabular}

Tablo 7'de yer alan analiz sonuçlarına göre e6-e9 yol katsayısının $(0,139)$ 0,05 anlamlılık düzeyinde, diğer modifikasyonların ise 0,001 düzeyinde istatistiksel olarak anlamlı olduğu tespit edilmiştir.

Algılanan faydanın kullanma niyeti, algılanan kullanım kolaylı̆ının kullanma niyeti ve algılanan kullanım kolaylığının algılanan fayda üzerinde istatistiksel olarak anlamlı bir etkisinin olup olmadığı yapısal eşitlik modeli ile incelenmiş olup sonuçlar Tablo 8'de gösterilmiştir. 
Tablo 8

Yapısal Eşitlik Modeli Regresyon Katsayıları

\begin{tabular}{|c|c|c|c|c|c|c|c|}
\hline & & & $\begin{array}{c}\text { Standardize } \\
\text { Edilmiş }\end{array}$ & $\begin{array}{l}\text { Standardize } \\
\text { Edilmemiş }\end{array}$ & S.E. & C.R. & $\mathbf{p}$ \\
\hline $\mathrm{AF}$ & $\leftarrow$ & KK & 0,136 & 0,136 & 0,104 & 1,306 & 0,192 \\
\hline $\mathrm{KN}$ & $\leftarrow$ & KK & 0,07 & 0,086 & 0,111 & 0,771 & 0,441 \\
\hline $\mathrm{KN}$ & $\leftarrow$ & $\mathrm{AF}$ & 0,518 & 0,638 & 0,112 & 5,679 & $* * *$ \\
\hline $\mathrm{KN}$ & $\leftarrow$ & $\mathrm{AF}$ & $\mathbf{R}^{2}=0,283$ & & & & \\
\hline \multicolumn{8}{|c|}{ Aracı Değişken Etkisi (Dolaylı Etki) } \\
\hline $\mathrm{KN}$ & $\leftarrow$ & $\mathrm{AF}$ & $\leftarrow$ & KK & $\beta=0,084$ & \multicolumn{2}{|c|}{$\begin{array}{l}\text { Güven Aralığ1 } \\
(-0,011 ; 0,221)\end{array}$} \\
\hline${ }^{*} \mathrm{p}<0,00$ & & & & & & & \\
\hline
\end{tabular}

Tablo 8'deki yapısal eşitlik modeli ile elde edilen regresyon katsayıları incelendiğinde algılanan faydanın kullanama niyeti üzerindeki etkisinin istatistiksel olarak anlamlı ( $<<0,001)$, algılanan kullanım kolaylığının algılanan fayda ve algılanan kullanım kolaylığının kullanma niyeti üzerindeki etkisinin istatistiksel olarak anlamsız olduğu görülmektedir. Modelde algılanan kullanım kolaylığının kullanma niyeti üzerindeki etkisinde algılanan faydanın aracılık rolü olup olmadığına da bakılmış olup algılanan fayda aracı değişkenine ait katsayı $(\beta=0,084)$ istatistiksel olarak anlamlı bulunmamıştır. Ayrıca algılanan fayda değişkeni, kullanma niyeti değişkeninde meydana gelen değişimlerin \%28,3'ünü açlklayabilmektedir.

\section{Sonuç}

Gün geçtikçe daha hızlı gelişen ve hayatımızın her alanında etkisi daha fazla hissedilen teknolojik gelişmeler, ilgili tüm alanlarda dijitalleşmeyi zorunlu kılmaktadır. Bireylerden kurum ve kuruluşlara kadar dijitalleşmenin etkisini hissedenler, faaliyetlerini dijital teknolojilerle yeniden düzenlemeye çalışmaktadır. Dijitalleşmeye bağlı olarak oluşan bu yeni yapı ise çalışma ortamlarının iyileşmesi, yeni kurulacak işbirlikleri ve hızlı veri akışının sağlanması ile alınabilecek daha tutarlı kararlar gibi pek çok avantajı da beraberinde getirmektedir. Gelişmiş veri tabanlarının kullanılması ve veri toplama araçlarının geliştirilmesi ile farklı iş kolları için sağlanan girdilerin, faaliyetleri geliştirmede de kullanılacağı düşünüldüğünde dijitalleşmenin etkisi daha net bir şekilde ortaya çıkmaktadır.

Dijital uygulamaların muhasebe sistemlerinde kullanılmasının ortaya çıkardığı değişimden muhasebe meslek mensupları oldukça etkilenmiştir. Meslek mensuplarının mesleki bilgilerine ek olarak bilgi teknolojilerini kullanma konusunda da bilgilere sahip olması faaliyetlerini sürdürebilmesi için gerekli bir hal almıştır. Diğer bir ifadeyle, bilgi teknolojileri kullanımı konusunda elde edilen yetkinlikler meslek mensuplarının faaliyetlerini sürdürebilmesinde önemli bir rol oynamaya başlamıştır. Dijital muhasebe uygulamaları muhasebe meslek mensuplarının etkin ve verimli çalışmasında katkı sağlayacak avantajlar sunmakla birlikte, bu noktada algılanan fayda ve kullanım kolaylığı faktörleri muhasebe meslek mensuplarının dijital muhasebe uygulamaları kullanım niyetleri üzerinde etkilidir.

Bu çalışmada Çorum'da bağımsız olarak çalışan SMMM'lerin dijital muhasebe uygulamaları ile ilişkili olarak algılanan kullanım kolaylığının algılanan fayda, algılanan kullanım kolaylığının kullanma niyeti ve algılanan faydanın kullanma niyeti üzerindeki etkisi yapısal eşitlik modeli kullanılarak incelenmiştir. Kullanılan örtük değişkenler ile gözlenen değişkenler arasındaki ilişki doğrulayıcı faktör analizi ile açıklanmış ve ölçüm modeli değerlendirilmiştir. Ayrıca yapısal eşitlik modelinde "Maximum Likelihood" yöntemi kullanılmış, modelde yer 
alan değişkenlerin normallik ve çoklu normallik varsayımlarını sağladığı gösterilmiş, model için hesaplanan uyum iyiliği indekslerinin kabul edilebilir seviyelerde olduğu ve kurulan modelin istatistiksel olarak anlamlı olduğu sonucuna ulaşılmıştır.

Çalışmanın amacı doğrultusunda SMMM’lerin dijital muhasebe uygulamalarına yönelik algılanan fayda, algılanan kullanım kolaylığı ve kullanma niyeti değişkenleri ile kurulan yapısal eşitlik modelinde çalışma için belirlenen hipotezler test edilmiştir. " $\mathrm{H}_{2}$ : Dijital muhasebe uygulamalarına yönelik SMMM'lerin algıladıkları faydanın, kullanma niyeti üzerinde pozitif bir etkisi vardır” hipotezi istatistiksel olarak anlamlı bulunmuştur. $\mathrm{Bu}$ sonuç Özer ve diğerleri (2010) ve Erdoğan (2020) ile uyumludur. " $\mathrm{H}_{1}$ : Dijital muhasebe uygulamalarına yönelik SMMM’lerin algıladıkları kullanım kolaylığının, algıladıkları fayda üzerinde pozitif bir etkisi vardır” ve " $\mathrm{H}_{3}$ : Dijital muhasebe uygulamalarına yönelik SMMM'lerin algıladıkları kullanım kolaylığının, kullanma niyeti üzerinde pozitif bir etkisi vardır” hipotezleri test edildiğinde, algılanan kullanım kolaylığının algılanan fayda ve kullanma niyeti üzerinde pozitif bir etkisi olmasına rağmen bu etkinin istatistiksel olarak anlamsız olduğu sonucuna ulaşılmıştır. Bu sonuç ise Özer ve diğerleri (2010) ve Erdoğan (2020) ile uyumlu değildir. Özet olarak bu çalışma kapsamında $\mathrm{H}_{2}$ hipotezi kabul edilirken, $\mathrm{H}_{1}$ ve $\mathrm{H} 3$ ve hipotezleri reddedilmiştir.

Elde edilen sonuçlara göre SMMM'lerin dijital muhasebe uygulamalarını kullanmaya yönelik niyetlerinin oluşmasında, bu uygulamaları kullanmaları durumunda sağlayacakları faydaları bir şekilde bilmeleri ya da öğrenmeleri gerekmektedir. Bu nedenle muhasebe meslek mensuplarına dijital muhasebe uygulamalarını öğreten ve bu uygulamaların sağladığı faydaları anlatan eğitimler verilerek yeterli donanıma sahip olmaları sağlanmalıdır. Ayrıca SMMM yeterlilik sınavlarına bilgi teknolojilerinin kullanımına yönelik bir dersin eklenmesi de önerilmektedir. Böylece her geçen gün daha da önemli hale gelen dijitalleşme ve beraberinde getirdiği uygulamalar sayesinde SMMM'ler çağın gerekliliklerine daha rahat uyum sağlayabilir. Bu çalışmanın en büyük kısıtı tek bir il ile sınırlandırılmış olmasıdır. TKM’nin temel faktörlerinin incelenmesi ise bir diğer kısıt olarak söylenebilir. Gelecek çalışmalar için farklı illerde ve TKM’nin geliştirilmiş versiyonlarının kullanılarak konunun ele alınması önerilmektedir. 


\section{Kaynakça}

Akdoğan, N. ve Akdoğan, M. U. (2018). Büyük veri bilişim teknolojisindeki gelişmelerin muhasebe uygulamalarına ve muhasebe mesleğine etkisi. Muhasebe ve Denetime Bakış, 18(55), 1-14. Erişim adresi: https://dergipark.org.tr/tr/pub/mdbakis/issue/63890/967128

Arslan, M. C. ve Demirkan, S. (2019). Endüstri 4.0 ve muhasebe sistemine etkisi üzerine kuramsal bir inceleme. Enderun, 3(1), 40-56. Erişim adresi: https://dergipark.org.tr/tr/ pub/enderun/issue/44778/548304

Arslan, M. C. ve Karkacier, A. (2019). Dijital dönüşüm sürecinde yönetim muhasebesinin geleceğini etkileyen faktörlere kavramsal bir bakış. Avrasya Sosyal ve Ekonomi Araştırmaları Dergisi, 6(6), 430-442. Erişim adresi: https://dergipark.org.tr/tr/pub/ asead/issue/47256/595897

Aslan, Ü. ve Özerhan, Y. (2017). Big data, muhasebe ve muhasebe mesleği. Muhasebe Bilim Dünyası Dergisi, 19(4), 862-883. Erişim adresi: https://dergipark.org.tr/tr/pub/mbdd/ issue/33192/331154

Atasel, O.Y. ve Şeker, Y. (2017). Uluslararası eğitim standartları ve uygulama açıklamaları kapsamında Türkiye'de muhasebe meslek sinavları ve eğitimlerinde bilgi teknolojilerine yeterli önem veriliyor mu?. B. Ayhan, M. Ay, S. Avşaroğlu \& Ş. Akpınar (Eds.), Sosyal ve Beşeri Bilimler Araştırmaları 2017 (s. 397407) içinde. Konya: Çizgi Kitabevi.

Bayraktar, C. ve Yıldırım, M. (2017). E-belge sistemleri üzerine davranışsal tutum ve kullanım niyetlerinin incelenmesi: Karabük ili muhasebe meslek mensupları örneği. Muhasebe ve Finansman Dergisi, (75), 95114. doi: 10.25095/mufad.399884

Bozkurt, O. ve Çakmak, N. B. (2020). Teknoloji kabul modeli perspektifinden bağımsız denetçilerin bilgisayar destekli denetim programlarını kullanıma ilişkin tutum ve davranışlarının potansiyel fayda beklentisi üzerine etkisi. Business \& Management Studies: An International Journal, 8(4), 607-646. doi: 10.15295/bmij.v8i4.1576

Browne, M.W. ve Cudeck, R. (1993). Alternative ways of assessing model fit. In: Bollen, K.A., \& Long, J.S. (Eds.), Testing structural equation models (p. 136-162). Beverly Hills, CA: Sage.

Çınar, O. ve Güney, S. (2012). Muhasebe meslek mensuplarının e-sorunlar. Ekev Akademi Dergisi, 16(50), 259272. Erişim adresi: https://arastirmax.com/en/system/files/dergiler/ 182912/makaleler/16/50/arastrmx_182912_16_pp_259-272.pdf

Davis, F. D. (1989). Perceived usefulness, perceived ease of use, and user acceptance of information technology. MIS Quarterly, 13(3), 319-340. doi:10.2307/249008

Davis, F.D., Bagozzi, R.P. ve Warshaw, P.R. (1989). User acceptance of computer technology: a comparison of two theoretical models. Management Science, 35(8), 982-1003.doi: 10.1287/mnsc.35.8.982

Davis, F.D., ve Venkatesh, V. (1996). A critical assessment of potential measurement biases in the technology acceptance model: three experiments. International journal of human-computer studies, 45(1), 19-45. doi: 10.1006/ijhc. 1996.0040

Dinç, E. ve Karakaya, A. (2004). Muhasebe meslek elemanlarının genel özelliklerinin e-muhasebe uygulamaları üzerine etkisi: doğu karadeniz bölgesi örneği. Karaman İİBF Dergisi, 1, 119-134. Erişim adresi: https://www.researchgate.net/publication/312901911_Muhasebe_Meslek_Elemanlarinin_Genel _Ozelliklerinin_E-Muhasebe_Uygulamalari_Uzerine_Etkileri_Dogu_Karadeniz_Bolgesi_Ornegi 
Elçin, R., Gerekan, B. ve Usta, M. (2018). E-fatura, e-defter ve e-arşiv uygulamalarına geçiş sürecinde yaşanan sorunlar: serbest muhasebeci mali müşavirler üzerine bir araştırma. Mali Çözüm Dergisi, (146), 13-42. Erişim adresi: https://app.trdizin.gov.tr/publication/ paper/detail/TXpBeE16Y3hNUT09

Erdem, A. ve Gülten, S. (2021). Dijital muhasebe uygulamaları. Ankara: Gazi Kitabevi.

Erdoğan, E. (2020). Dijital muhasebe uygulamaları kullanımının teknoloji kabul modeli ile incelenmesi: Muhasebe meslek mensupları üzerine bir araştırma. (Yayımlanmamış Yüksek Lisans Tezi). İnönü Üniversitesi, Malatya.

Erturan, İ. E. ve Ergin, E. (2018). Büyük verinin muhasebe ve denetim alanlarına uyumu. Akademik Sosyal Araştırmalar Dergisi, 6(81), 208-222. doi:10.16992/ASOS.14255

Esmeray, A. (2018). Bilişim teknolojisindeki gelişmelerin muhasebe denetimine katkısı. Muhasebe Bilim Dünyası Dergisi, 20, 294-309. Erişim adresi: https://dergipark.org.tr/tr/pub/mbdd/issue/42789/517652

Fishbein, M. ve Ajzen, I. (1975). Belief, attitude, intention, and behavior: An introduction to theory and research. Addison-Wesley, Reading, MA.

Gökçen, G. ve Özdemir, M. (2016). Türkiye'de muhasebe uygulamalarından e-defter ve e-fatura uygulaması. Öneri Dergisi, 12(46), 137-154. doi:10.14783/od.v12i46.1000010008

Gönen, S. ve Solak, B. (2017). Maliye bakanlığı e-dönüşüm sürecinin muhasebe meslek mensupları açısından değerlendirilmesine ilişkin bir alan araştırması. Muhasebe ve Finansman Dergisi, (76), 63-80. doi: 10.25095/mufad.400219

Güney, S. ve Özyiğit, H. (2015). Muhasebedeki verilerin yönetimde kullanılması ve elektronik muhasebe verilerinin yönetim kararlarına etkisi. Elektronik Sosyal Bilimler Dergisi, 14(53), 279. doi:10.17755/esosder.48280

Hatunoğlu, Z. ve Bakan, İ. (2010). Muhasebe bürolarında bilgisayar ve internet kullanımının faydaları ile muhasebe meslek mensuplarının demografik nitelikleri arasındaki ilişkiler: bir alan araştırması. World of Accounting Science, 12(2), 98-129. Erişim adresi: https://dergipark.org.tr/tr/download/articlefile/183255

Hoş, S. ve Bağcı, B. (2020). Genç nüfusun marka ve mağaza sadakatinin satın alma davranışları üzerine etkisi. H. Kahraman ve Y. T. Yıldırım (Eds.), Çivi Yazısından Dijital Kodlamaya Ekonomi, İşletme Ve Finans Çalışmaları. (s. 113-128) içinde. Ankara: Ekin Yayınevi

Karasioğlu, F. ve Garip, O. (2019). E-muhasebe uygulamaları kapsamında güncel sorunlar ve çözüm önerileri: Karaman'da bir araştırma. Selçuk Üniversitesi Sosyal Bilimler Meslek Yüksekokulu Dergisi, 22(2), 433446. Erişim adresi: https://dergipark.org.tr/en/download/article-file/844171

Kline, R. B. (2005). Principles and practice of structural equation modeling. New York: Guilford.

Lian, J.-W. (2015). Critical factors for cloud based e-invoice service adoption in Taiwan: An empirical study. International Journal of Information Management, 35(1), 98-109. doi:10.1016/j.ijinfomgt.2014.10.005

Marinagi, C., Trivellas, P., Reklitis, P. ve Skourlas, C. (2015). Adoption and use of e-invoicing in Greece. AIP Conference Proceedings, 1644(1), 279-286. doi:10.1063/1.4907848

Özcan, M. ve Günlük, M. (2021). Muhasebe meslek mensuplarının Türkiye finansal raporlama standartlarını kabullerinin teknoloji kabul modeli çerçevesinde incelenmesi. İşletme Akademisi Dergisi, 2(1), 76-93. doi: 10.26677/TR1010.2021.702 
Özer, G., Özcan, M. ve Aktaş, S. (2010). Muhasebecilerin bilgi teknolojisi kullanımının teknoloji kabul modeli (TKM) ile incelenmesi. Yaşar Üniversitesi E-Dergisi, 5(19), 3278-3293. doi:10.19168/jyu.69780

Özer, G. ve Yılmaz, E. (2010). Mantıklı eylem teorisi (MED) ile muhasebecilerin bilgi teknolojisi kullanımına yönelik bir uygulama. İktisat Isşletme ve Finans, 25(290), 65-88. doi: 10.3848/iif.2010.290.2463

Schermelleh-Engel, K., Moosbrugger, H., ve Müller, H. (2003). Evaluating the fit of structural equation models: Tests of significance and descriptive goodness-of-fit measures. Methods of psychological research online, 8(2), 23-74. Erişim adresi: https://psycnet.apa.org/record/2003-08119-003

Serçemeli, M. ve Kurnaz, E. (2016). Denetimde bilgi teknoloji ürünleri kullanımının teknoloji kabul modeli (TKM) ile araştırılması. İstanbul Üniversitesi İşletme Fakültesi Dergisi, 45(1), 43-52. Erişim adresi: https://dergipark.org.tr/tr/pub/iuisletme/issue/30530/330269

Spoz, A. (2014). A look at e-invoices from enterprices' and government's perspective. Prace Naukowe Uniwersytetu Ekonomicznego we Wrocławiu, (365), 254-264. doi:10.15611/pn.2014.365.21

Şençiçek Tektüfekçi, F. (2013). Bilişim teknolojilerindeki gelişmelerin muhasebe uygulamalarına etkisi: emuhasebe. Sosyal ve Beşeri Bilimler Dergisi, 5(2), 89-102. Erişim adresi: https://dergipark.org.tr/tr/pub/sobiadsbd/issue/22122/237592

Tabachnick, B. G., ve Fidell, L. S. (2013). Using multivariate statistics: International edition. Boston: Pearson.

Tektüfekçi, F. (2017). E-dönüşüm sürecinde e-muhasebe uygulamaları: Türkiye örneği. Bilgi Ekonomisi ve Yönetimi Dergisi, $\quad$ 12(1), 79-88. Erişim adresi: https://dergipark.org.tr/tr/pub/beyder/issue/31845/318052

Tektüfekçi, F. (2019). Endüstri 4.0 kapsamında dijital dönüşümün güncel elektronik muhasebe uygulamalarına yansıması ve pragmatik yaklaşım olarak mali mühendislik. Bilgi Ekonomisi ve Yönetimi Dergisi, 14(1), 43-56. Erişim Adresi: https://dergipark.org.tr/tr/pub/beyder/issue/46315/458539

Tosunoğlu, B. ve Öztürkci, N. (2020). Dijital okuryazarlığın alt boyutlarının muhasebe mesleği üzerindeki etkisi: TR90 bölgesi muhasebe meslek mensupları örneği. Muhasebe ve Vergi Uygulamaları Dergisi, 13(3), 571-587. doi: 10.29067/muvu.652081

Tuğay, O. ve Güler, A. (2021). Elektronik muhasebe uygulamaları konusunda muhasebe meslek mensuplarının görüşleri: Isparta ilinde bir araştırma. Muhasebe ve Vergi Uygulamaları Dergisi, 14(2), 695-726. doi: 10.29067/muvu.705569

Venkatesh, V., ve Bala, H. (2008). Technology acceptance model 3 and a research agenda on interventions. Decision sciences, 39(2), 273-315. doi:10.1111/j.1540-5915.2008.00192.x 


\section{Extended Abstract}

\section{Aim and Scope}

The aim of this study is to reveal professional accountants' perspectives on the use of digital accounting practices. The opinions of professionals on the factors of perceived usefulness, perceived ease of use, and behavioral intention digital accounting practices were determined for this purpose, and the relationships between these factors were revealed. Considering that almost all accounting practices are now performed digitally, it is important to reveal accounting professionals' digital accounting practices behaviors.

\section{Methods}

The main body of the study is made up of 209 CPAs in Çorum. Because the number was available, the total count model has been used, and the questionnaire form created in the Google Forms application was distributed to the entire population. The study was carried out using the responses of $95 \mathrm{CPA}$ who responded to the survey. The first section of the survey includes questions about demographic characteristics. There are statements about digital accounting practices in the second section. To respond to the statements, 5-point Likert scale has been used, with the scale being expressed as '1-Strongly Disagree, 2-Disagree, 3-Undecided, 4Agree, 5-Strongly Agree.'

The structural equation model was used to investigate the effect of ease of use on perceived usefulness, ease of use on behavioral intention, and perceived usefulness on intention to use in relation to digital accounting practices used by CPAs. Since previous studies revealed the construct validity of the scale, which includes the factors used in the study, the structural equation model was used directly in this study, and the structural model's necessary assumptions have been provided. Confirmatory factor analysis has been used to explain the relationship between the latent variables used and the observed variables, and the measurement model was evaluated. Furthermore, in the structural equation model, the "Maximum Likelihood" method was used, and it was indicated that the variables in the model met the normality and multiple normality assumptions. The goodness of fit indexes calculated for the model were found to be acceptable, and the established model was statistically significant.

\section{Findings}

The hypotheses determined for the study have been tested in the structural equation model established with the variables of perceived usefulness, ease of use, and behavioral intention CPAs for digital accounting practices for the purpose of the study. The hypothesis " $\mathrm{H}_{2}$ : "The perceived usefulness of CPAs for digital accounting practices has a positive effect on behavioral intention" has been found to be statistically significant. This result is consistent with the findings Özer et al. (2010) and Erdoğan (2020). After testing the $\mathrm{H}_{1}$ : "The perceived ease of use of CPAs for digital accounting practices have a positive effect on their perceived usefulness" and $\mathrm{H}_{3}$ : "The perceived ease of use of CPAs for digital accounting practices has a positive effect on the behavioral intention" hypotheses, it was determined that, while ease of use had a positive effect on perceived usefulness and behavioral intention, the effect was statistically insignificant. This finding contrasts the findings of Özer et al. (2010) and Erdoğan (2020). In conclusion, the $\mathrm{H}_{2}$ hypothesis was accepted in this study, but the $\mathrm{H}_{1}$ and $\mathrm{H}_{3}$ hypotheses were rejected. 


\section{Conclusion}

According to the results, it has been determined that in order for CPAs to form a behavioral intention digital accounting practices, they should first understand or learn about the benefits that these practices will provide. For this reason, professional accountants should be provided with trainings that teach digital accounting practices and explain their benefits, so that they have adequate equipment. It is also suggested that the CPA proficiency exams include a course on information technology. As a result, digitalization, which is becoming increasingly important, and the practices it brings, can be better learned, and CPAs can more easily adapt to the demands of the age.

The biggest limitation of this study is that it is restricted to a single province. Examining the basic factors of TAM can be said as another limitation. It is suggested that future research be conducted in different provinces and with improved versions of TAM.

Araştırmacı Katkısı: Yasin ŞEKER (\%50), Safa HOŞ (\%50). 